\title{
Trends on Bio-Synthesis of Plastics
}

\author{
Ezeonu Chukwuma Stephen* and Dada Folashade Temitope \\ Department of Biochemistry, Federal University Wukari, Nigeria
}

Submission: June14, 2018; Published: September 04, 2018

*Corresponding author: Ezeonu Chukwuma Stephen, Department of Biochemistry, Industrial Biochemistry \& Biotechnology Unit, Federal University Wukari, Taraba State, Nigeria, Tel: +2348066919780; Email: chuksmaristos@yahoo.com

\begin{abstract}
This work gives an overview on bioplastics, focusing on their synthesis from biomass sources. It equally deals with different classes of bioplastics and their possible sources. The background challenge it proffers solution to is that of conventional plastics of petroleum origin, widely in use which has become undesirable due to their non-biodegradable nature and the attendant environmental problems which negate their otherwise great usefulness. This research attempts to also emphasize the incidence of polymer components in biomass and the biochemical approaches of synthesizing these polymers into bioplastics. Finally, it introduced different biopolymers currently researched. With more innovations in biopolymer technology, it is hoped that bioplastic will be of more usefulness in the near future.
\end{abstract}

Keywords: Biodegradable; Biomass; Bioplastics; Biopolymer; Plastics; Technology; Synthesizing; Environment; Petrochemicals; Plants; Pollution; Statistic; Nutrient; Microorganisms; Bacteria; Molecules; Carbon; Alcaligenes eutrophus; Methylo bacterium; Pseudomonas aeruginosa

Abbreviations: PLA: Plastics Like polylatic Acid; PHA: Poly Hydroxy Alkanoates; SA: Starch Acetate; PE: Poly Ethanol; PVA: poly hydroxy Valerate

\section{Introduction}

Petrochemical being the major source of production of plastics has quite a number of limitations; first, it is exhaustible, secondly, products of petrochemicals are non-biodegradables and eco-contaminants. Petrochemical bioplastics just like crude oil, contaminates soils and has negative impact on the growth of plants particularly Zea mays [1]. The resources utilizable for generation of alternative energy, bioplastics inclusive in form of oil seeds, agro-wastes and lignocelluloses are currently in the forefront of research into alternative energy [2].These reasons above then informed the need to seek for alternative to conventional plastic production. This replacement is the bioplastic from biopolymers. Synthesis of bioplastics is generally considered very ecofriendly as compared to conventional plastic production from petroleum hydrocarbon sources. Braunegg et al. [3] explained that biomaterials are natural products synthesized and catabolized by different organisms and have broad biotechnological applications. Additionally, biomaterials can be assimilated by many species and do therefore possess biocompatibility with the host.

In this way, they confer upon them a considerable advantage with respect to other conventional synthetic products. Bioplastics are biomaterials that are polyesters produced by a range of microbial sources, and plants under different nutrient and environmental conditions [3]. They are derived from renewable biomass sources, such as vegetable oil, corn starch, and pea starch [4]. The reason for this is that the former relies less on fossil fuel as a carbon source and also hazardous waste released is lesser or even negligible when compared to that of oil-derived plastics [5]. In Europe, bioplastics account for $60 \%$ of the biodegradable materials market. The most common end use market is for packaging materials. Japan has also been a pioneer in bioplastics, incorporating them into electronics and automobiles [5]. Avella et al. [6] explained that the production and the use of plastics in the world have been enormously increased in the past 20 years. Averous \& Pollet [7] emphasized that most of today's synthetic polymers are produced from petrochemicals and are not biodegradable. Environmental pollution may be very harmful to the biota; both aquatic and terres trials when there is continuous generation of chemical polymers not properly disposed in a locality. According to Agnieszka et al. [8], there is a worldwide statistic in which an estimated 43 percent of marine mammal species, 86 percent of sea turtle species, and 44 percent of sea bird species are susceptible to ingesting marine plastic debris. Also, plastic production has increased from 0.5 to 260 million tonnes per year since 1950 . It was discovered that $40 \%$ of plastics produced every year are discarded into Landfill [9]. Moreover, more than 500 billion plastic bags are distributed every year, and less than $3 \%$ bags are recycled. They are typically made of polyethylene and can take up to 1,000 years to degrade in landfills that emit harmful greenhouse gases [9]. 


\section{Bioplastics}

Bioplastics are organics produced from biological sources which have both airtight and water proof properties. According to Asta [10], the standardization work of bioplastics was initiated in Europe and the USA; to date, however, there is no universal established practice on the definitions for bioplastics Furthermore, there is no legislation regulating the amount of renewable sourced material that needs to be present in a plastic for it to be called 'bioplastic' or for the measurement and reporting of renewable content of a bioplastic. The ultimate goal beyond the mere reporting of renewable content, is likely to be a framework for providing a fuller assessment of each material's life-cycle and carbon footprint [11].

\section{The latest definitions according to Frost and Sullivan [11], biopolymers and bioplastics can refer to:}

a. Bio-based and biodegradable plastics like polylatic acid (PLA), poly hydroxy alkanoates (PHA) and s t a r c h acetate (SA)

b. Bio-based, non-biodegradable plastics like polyamides and bio-based Poly Ethanol (PE);

c. Synthetic biodegradable polymers, e.g. Poly Hydroxy Valerate (PVA).

The fastest growing and most interesting group is the biobased/renewable resourced plastics, which are introducing to the market a number of bio-based plastics with the same properties as conventional plastics. At present, the most commonly used commercial bioplastics are PLA and starch-based plastics. PHAs, biopolymer blends and some bio-sourced thermoset materials, such as furan resin, also exist [11]. Bioplastics are plastics derived from renewable biomass sources, such as vegetable fats and oils, corn starch, or microbiota [12]. Hong et al. [12] further stated that bioplastic can be made from agricultural by products and also from used plastic bottles and other containers using microorganisms.

\section{Types of bioplastics}

Jajani and Rajarajan [13], mentioned that bio-based polymers may be divided into three main categories based on their origin and production

a. Category 1: polymers directly extracted/removed from biomass. Examples are polysaccharides (starch and cellulose) and proteins (casein and gluten).

b. Category 2: polymers produced by classical synthesis using renewable bio-based monomers. A good example is poly acetic acid, a bio polyester polymerized from lactic acid monomers. The monomers themselves maybe produced via fermentation of carbohydrate feedstock.

c. Category 3: polymers produced by microorganisms or genetically modified bacteria. To date, this group of bio-based polymers consists mainly of the polyhydroxy alkenoate, but development with bacterial cellulose is in progress.

\section{Biological sources of bioplastics}

Reddy et al. [14] explained that plastics produced conventionally are from non-renewable hydrocarbon resources. Also having long polymer molecules tightly bound to one another makes them non-biodegradable especially to microorganisms. Bio-plastics can be made using polymers from bacteria, algae and plants as made up of more easily shorter degraded polymers and therefore the best option for such purpose. Following is a brief account of how each group of organisms may be utilized for the purpose.

\section{Algae}

According to Reddy et al. [14], algae serve as an excellent feedstock for plastic production owing to its many advantages such as high yield and the ability to grow in a wide range of environments. Algae bioplastics mainly evolved as a byproduct of algae biofuel production, where companies were exploring alternative sources of revenues along with those from biofuels. In addition, the use of algae opens up the possibility of utilizing carbon, neutralizing greenhouse gas emissions from factories or power plants. Utilization of feedstocks from corn and potatoes for plastics biosynthesis being the traditional method of producing biodegradable plastics, is currently being overtaken by the use of algae in its synthesis. Meanwhile algae-based plastics are still evolving, when eventually commercialization, they are likely to find applications in a wide range of industries. However, before commercialization is realized, many technical problems must be over comed. Cereplast, the company which produces 'Cereplast Algae Plastics', makes them from 50\% algae. Plastics that comprise material derived $100 \%$ from algae are still not a reality and require innovative dimprovement to be realized. The use of biotechnological techniques can play a key role in conducting the feasibility and sustainability studies in algae bioplastics [15].

\section{Fungi}

The contribution of this group of organisms towards bioplastic production is still not perceptible, but since they consist of biopolymers, they are possibilities.

\section{Plants}

Reddy et al. [14] further explained that plants are capable of producing large amounts of a number of useful chemicals at a low cost compared to that of bacteria or yeast. Commercialization of plant derived bioplastics, particularly PHAs (poly-3hydroxybutyrates) will require the creation of transgenic plants that in addition to possessing high product yields should have normal plant phenotypes and transgenes that are stable over several generations. In contrast to bacteria, plant cells are highly compartmentalized hence the desired genes for example PHB must be targeted to the compartment of the plant cells where the concentration of the precursor molecule is high. 
Many oil crops such as rapeseed, sunflower and soybean could be potentially engineered for the production of PHA (poly hydroxy alkanoates). The other plants currently in use for PHA production are Gossypium hirsutum and Zea mays. The advantage looks more with the starch-producing crops than oil crops in terms of yield ( $\mathrm{kg} /$ hectare) but the diversion of precursor molecules towards PHB synthesis is likely to be more complex in starch crops since the flux of carbon is primarily directed towards sucrose (Figure $1 \& 2$ ).

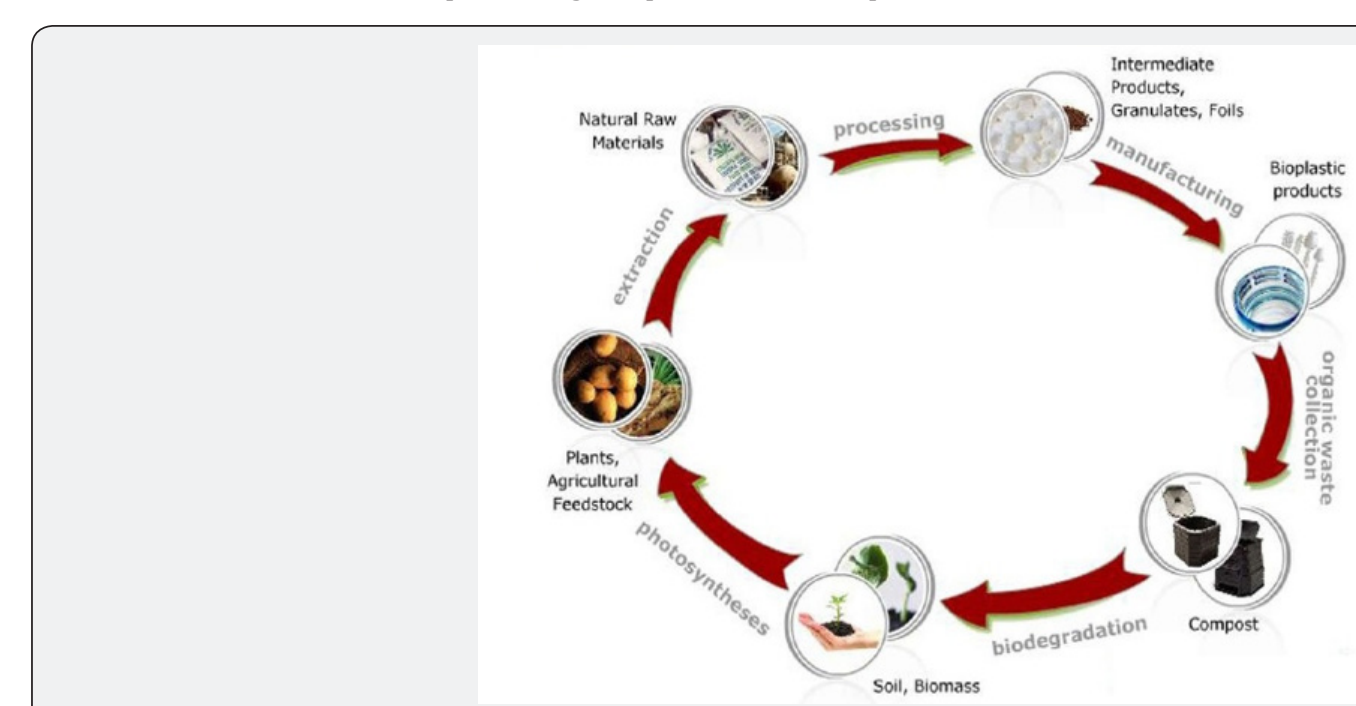

Figure 1: Life cycle representation of bioplastics.

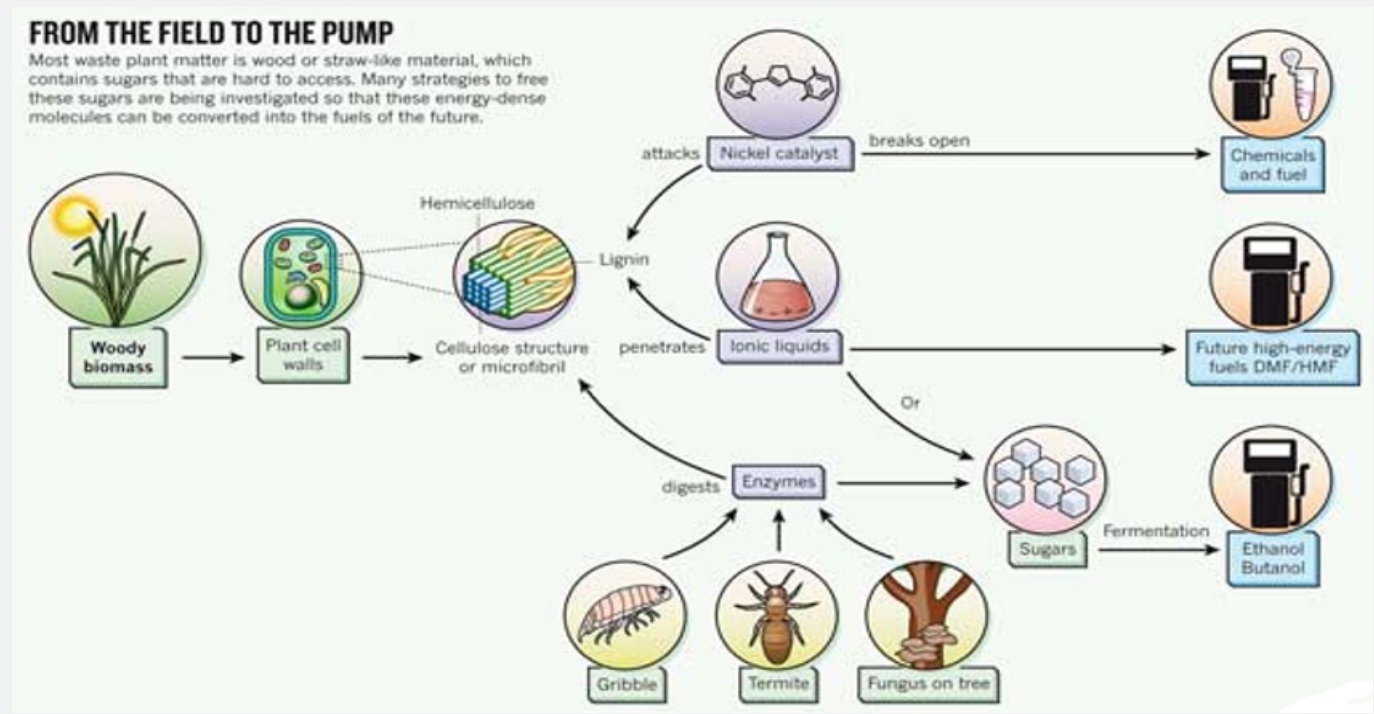

Figure 2: An Overview of Bioplastics.

According to Reddy et al. [14], bacteria are so far the most widely studied organisms with regard to production of bioplastics. Particularly, PHAs are synthesized by many grampositive and gram-negative bacteria from at least 75 different genera. PHAs extracted from bacterial cells show material properties that are similar to polypropylene [3]. These polymers are accumulated intracellularly to levels as high as $90 \%$ of the cell dry weight under conditions of nutrient stress and act as a carbon and energy reserve (Figure 2) [14]. The occurrence of PHAs in bacteria has been known since 1920s, when Lemoigne reported the formation of Poly 3-HydroxyButyrate (PHB) inside bacteria, also the cytoplasmic membrane and cytoplasm of
Escherichia coli have been discovered to contain non-storage PHA that are of low molecular weight. The following are some of the most important bacterial species utilized for the production of PHAs: Alcaligenes eutrophus, Bacillus megaterium QMB1551, Klebsiella aerogenes recombinants, Methylo bacterium rhodesianum MB 1267, Pseudomonas aeruginosa, P. denitrificans, P. putida, P. oleovorans and Sphaerotilus natans [14].

\section{Plants}

Lemoigne [5] and Verlinden et al. [16] stated that the main candidates for the large-scale production of PHAs are plants and bacteria. However, plant cells give very low yields $[<10 \% \mathrm{w} / \mathrm{w}$ 
dry weight]. High levels [10 - 40\% w/w dry weight] have been shown to have a negative effect on growth and development of plant. In bacteria they can be accumulated up to $90 \%$ of the cell dry weight. Accumulating PHAs is a natural way for bacteria to store carbon and energy, when nutrient supplies are imbalanced. While the most common limitation is nitrogen, for some bacteria, such as Azotobacter sp., the most effective limitation is oxygen [17]. The first PHA to be discovered and therefore the most studied is PHB. In their metabolism, bacteria produce acetylcoenzyme-A (acetyl-CoA), which is converted into PHB by three biosynthetic enzymes (Figure 3 \& 4) (Table 1).

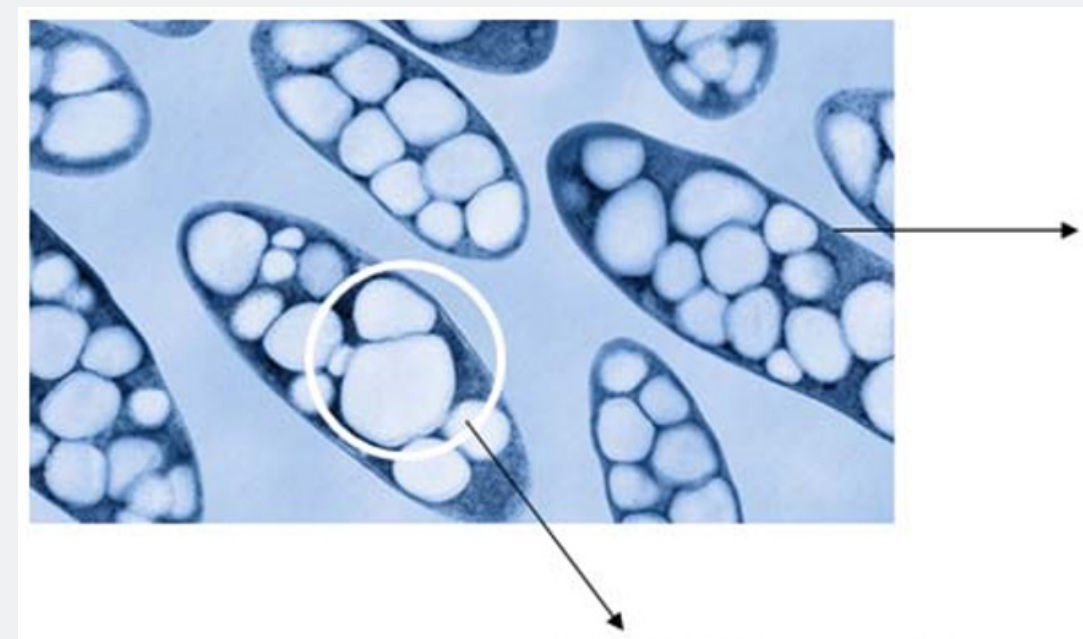

\section{Bacterial cell}

\section{Accumulated PHA granules}

Figure 3: Intracellular accumulation of PHAs in bacterial cells.

Table 1: Types and Properties of Bioplastics.

\begin{tabular}{|c|c|c|}
\hline S. No. & Types & Properties \\
\hline 1 & $\begin{array}{l}\text { Starch-based } \\
\text { plastics }\end{array}$ & $\begin{array}{c}\text { The thermoplastic starch, such as plastarch material, } \\
\text { currently represents the most important and } \\
\text { widely used bioplastic. }\end{array}$ \\
\hline 2 & $\begin{array}{l}\text { Aliphatic } \\
\text { polyesters }\end{array}$ & $\begin{array}{l}\text { The aliphatic biopolyesters are mainly polyhydroxy } \\
\text { alkanoates (PHAs) like the poly-3-hydroxybutyrate } \\
\text { (PHB), polyhydroxyvalerate (PHV) and } \\
\text { polyhydroxyhexanoate PHH. }\end{array}$ \\
\hline 3 & $\begin{array}{c}\text { Polylactic } \\
\text { acid (PLA) plastics }\end{array}$ & $\begin{array}{l}\text { PLA is a transparent plastic } \\
\text { produced from cane sugar or glucose. }\end{array}$ \\
\hline 4 & $\begin{array}{l}\text { Poly-3-hydroxy } \\
\text { butyrate (PHB) }\end{array}$ & $\begin{array}{c}\text { The biopolymer poly-3-hydroxybutyrate (PHB) } \\
\text { is polyester produced by certain } \\
\text { bacteria processing glucose or starch. }\end{array}$ \\
\hline 5 & $\begin{array}{l}\text { Polyamide } \\
11 / \text { PA } 11\end{array}$ & $\begin{array}{l}\text { PA } 11 \text { is a biopolymer derived from natural oil. } \\
\text { PA } 11 \text { belongs to the technical polymers family and } \\
\text { is not biodegradable. It is used in high-performance } \\
\text { applications like automotive fuel lines, } \\
\text { pneumatic airbrake tubing, electrical cable etc }\end{array}$ \\
\hline 6 & $\begin{array}{l}\text { Bio-derived } \\
\text { polyethylene }\end{array}$ & $\begin{array}{l}\text { The monomer of polyethylene is ethylene. } \\
\text { This is produced by fermentation of } \\
\text { agricultural feedstocks such as sugarcane or corn. }\end{array}$ \\
\hline
\end{tabular}




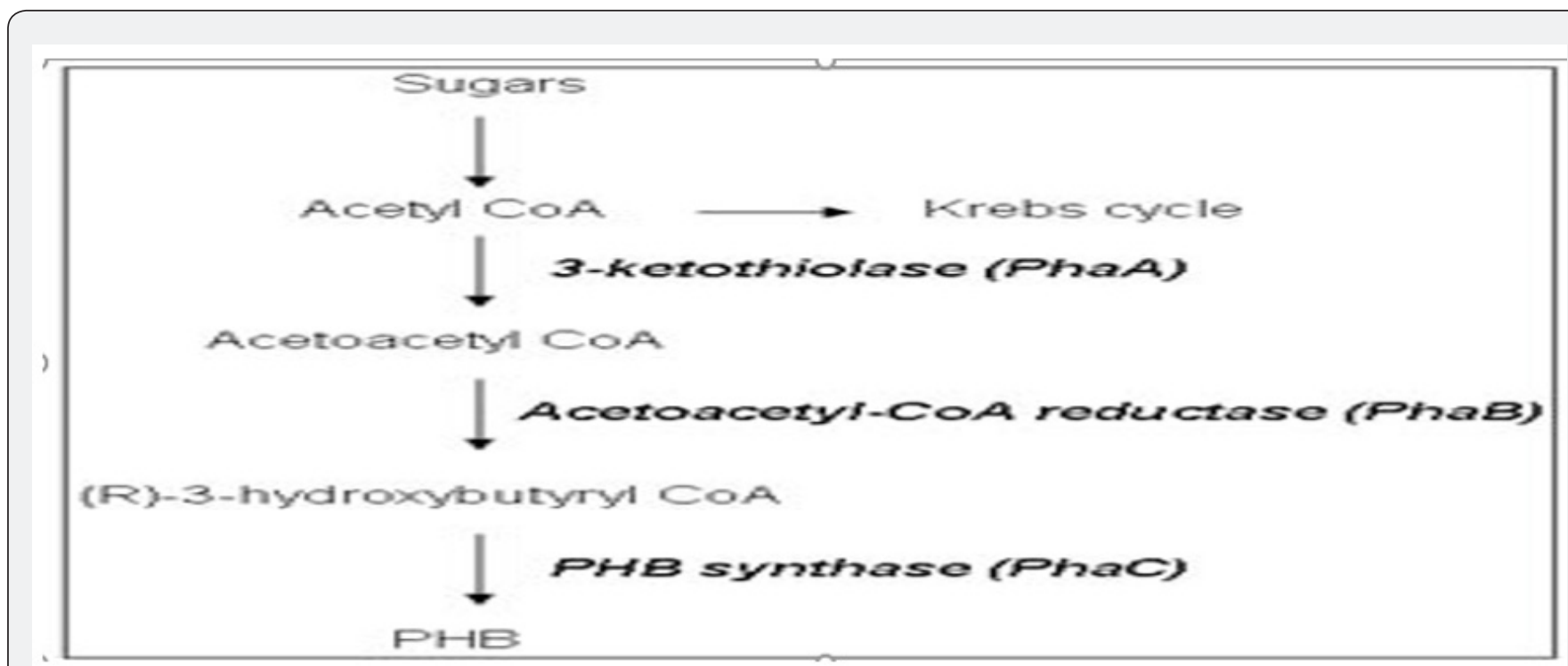

Figure 4: Metabolic Pathway for PHB Synthesis.

\section{Some of these bioplastics illustrated in table above are further explained below}

Starch based plastics: The major plant storage form of glucose is the starch. It consists of two components: amylose, in which the glucose unit are 1,4- $\alpha$-D- linked together in straight chains (Figure 3), and amylopectin, in which the glucose chain are highly branched [17-19]. In addition, Ramesh et al. [21] also explained that starch has different proportion of amylase and amylopectin ranging from $10-20 \%$ amylase and $80-90 \%$ amylopectin depending on the sucrose. Starch can be oxidized and reduced, and may participated in the formation of hydrogen bonds, ethers and esters [22]. The hydrophilicity of starch can be used to improve the degradation rate of some degradable hydrophobic polymers [23]. Principally, there are three ways how starch can be used for biodegradable polymer production. The first one is the preparation of starch composition with other plastics with a low amount of starch to enhance the biodegradability of traditional oil-based polymer materials. The second way of starch application is the preparation of starch composite with starch content being more than half by mass and third way of starch biodegradable polymers preparation uses the extrusion processing of mixtures of granular starch [24].

\section{Cellulose based bioplastics}

Cyras et al. [25] \& Liu [23] concurred that cellulose is the most widely spread natural polymer and is derived by a delignification from wood pulp or cotton linters. According to them, it is a biodegradable polysaccharide which can be dissolved in a mixture of sodium hydroxide and carbon di sulphide to obtain cellulose xanthate and then recast into an acid solution (sulfuric acid) to make a cellophane film. Petersen et al. [26] explained that alternatively, cellulose derivatives can be produced by recovery of cellulose from the solvated state, via esterification or etherification of hydroxyl groups. These cellulose derivatives became the subject of recent research Sources [26-28] (Figure $5)$.
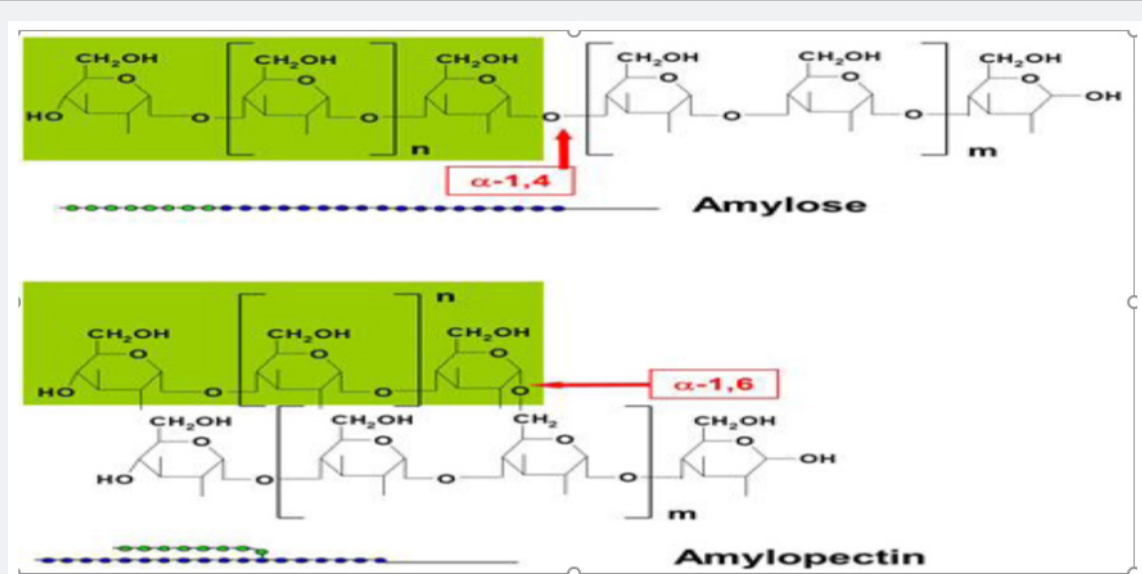

Figure 5: Structure of Amylose and Amylopectin (di) acetate and cellulose (tri)acetate need addition of additives to produce thermoplastic materials. Most of them can be processed by injection molding or extrusion. 


\section{Pectin}

Pectin is a linear macromolecule constituted of $\alpha$ (1-4)-linked D-galacturonic acid (Figure 6). This monomer unit could be partially replaced by $\alpha$ (1-2)-linked L-rhamnose leading to a new structure named rhamnogalacturonan I. Rhamnogalacturonan II, is a third type of structural pectin which is less frequent, but complex and highly branched polysaccharide [29]. In nature, around $80 \%$ of the galacturonic acid carboxyl groups are esterified with methanol. This proportion depends on the extraction conditions. Since the ratio of esterified/non-esterified galacturonic acid determines the behavior of pectin in food applications, pectins are classified as high or low ester pectins $[30,31]$.

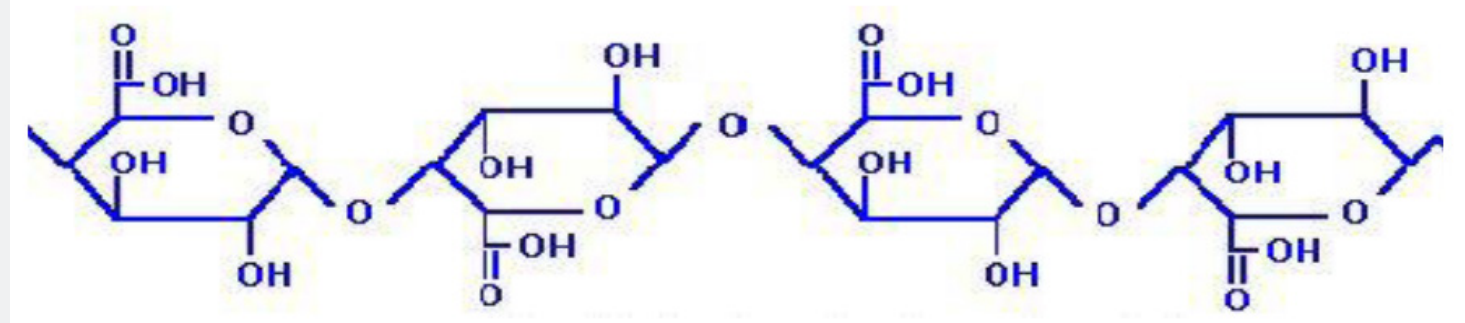

Figure 6: Pectin (Polygalacturonic acid).

\section{Chitin and Chitosan}

Chitin is the second most abundant agro-polymer produced in nature after cellulose. It appears in nature as ordered crystalline microfibrils forming structural components in the exoskeleton of arthropods or in the cell walls of fungi and yeasts [32]. It is biodegradable, nontoxic and readily bio compactible [33]. Flieger et al. [24], detected that usually, chitin is extracted from crab crumb and during a pre-treatment phase dilute solution of sodium hydroxide ( $\mathrm{pH}$ 13.5) dissolved any remaining flesh and prevents further microbial activity or shell degradation. The crushed shells are conveyed into reactor, where they are treated with hydrochloric acid to gasify the materials. In the third stage of process, to liquefy proteins and produce chitin, the material is washed before entering another $\mathrm{NaOH}$ solution with a slightly elevated temperature on a dry mass basis there is $12 \%$ yield in the process of extracting chitin from crab crumb. Chitosan is produced from chitin (Figure 7). It is washed and put through boiling lye to remove acetate from the molecule. After hydrolysis, the resulting chitosan is washed, dried, ground, weighed and packed for sale [23,31,32].

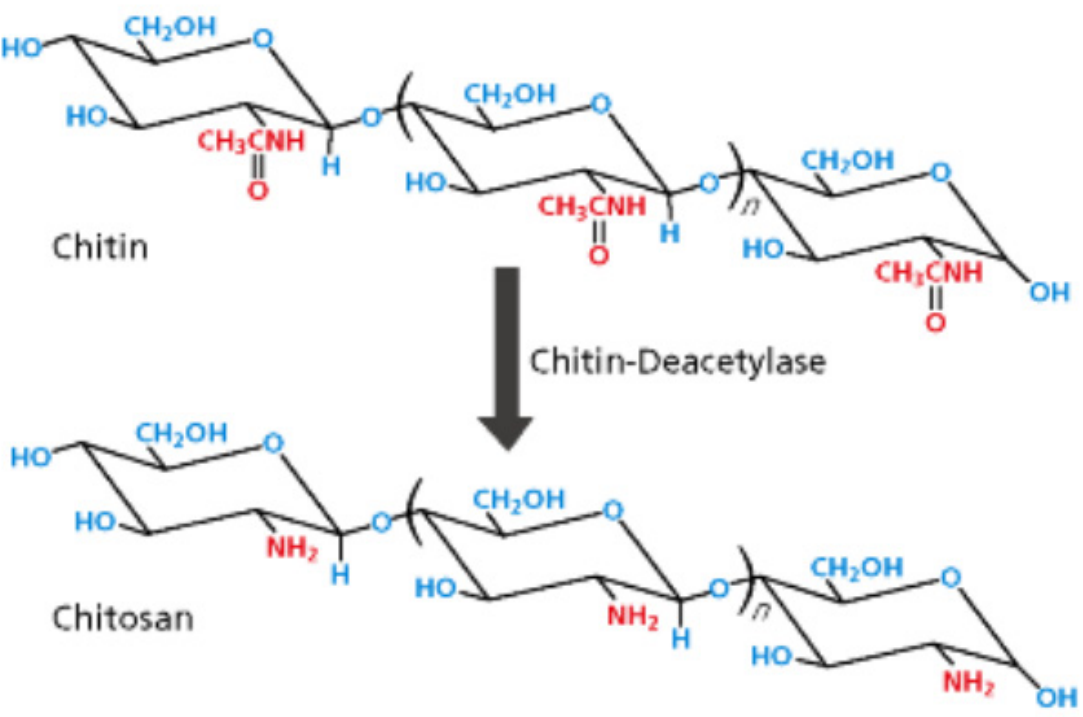

Figure 7: Chitin and Chitosan.

\section{Protein}

Averous \& Pollet [7], stated that a certain number of protein have received much attention as biodegradable polymer but few have led to actual industrial scale up due to the high production cost and the low product performance. In terms of potential sources, soy protein, corn protein (zein) and wheat proteins (gluten) are among the main plant proteins. Casein, collagen protein or gelatin, and keratin are important animal proteins. Casein, collagen protein or gelatin, and keratin are important animal proteins. Lactate dehydrogenase, chymotrypsin, and fumarase constitute the main bacterial $[7,33]$. 


\section{Some Aliphatic Polymers}

Bio polyesters that are aliphatic consist mainly of poly Hydroxy Alkanoates (PHAs) like the Poly Hydroxy Valerate (PHV), Poly-3- HydroxyButyrate (PHB), Poly Butylene Succinate (PBS) and poly Hydroxy Hexanoate (PHH). These are potentials for synthesis of bioplastics.

\section{Polylactic Acid (PLA)}

Mulch film made of polylactic acid (PLA)-blend or bio-flex Polylactic acid (PLA) is a transparent plastic produced from corn [34] or dextrose. Royte [35], further stated that its (PLA) characteristics are similarto conventional petrochemical-based mass plastics like PolyEthylene Terephthalate(PET), PolyStyrene (PS) or Poly Ethanol(PE) and it can be processed using standard equipment that already exists for the production of some conventional plastics. Figure 8 below shows pathway links of biochemical intermediates involved in the synthesis of PLA. PLA and PLA blends generally come in the form of granulates with various properties and are used in the plastic processing industry for the production of films, fibers, plastic containers, cups and bottles.

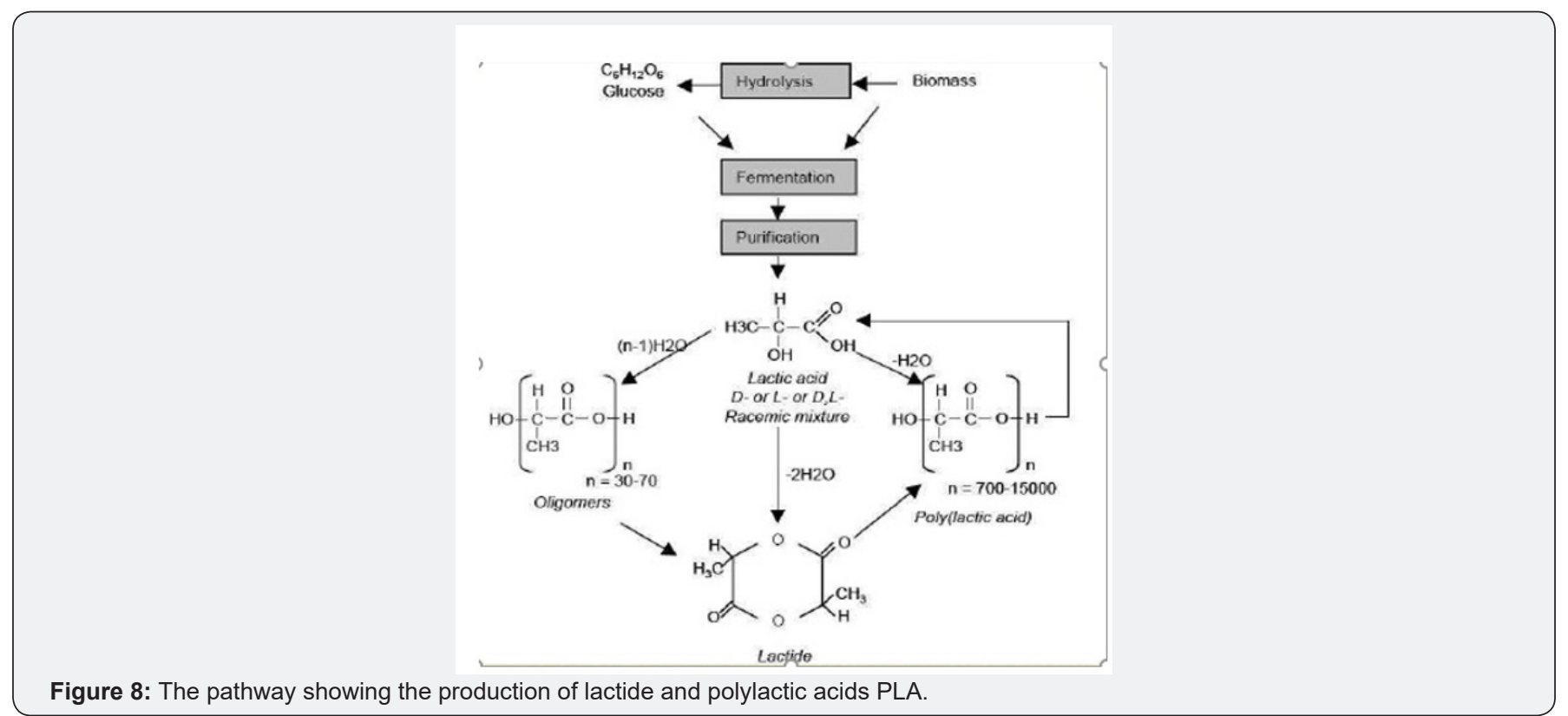

\section{Poly Hydroxy Alkanoates (PHA)}

Polyhydroxyalkanoates, as explained by Suszkiw [36], are linear polyesters produced in nature by bacterial fermentation of sugar or lipids. They are produced by the bacteria to store carbon and energy. In industrial production (Figure 9), the polyester is extracted and purified from the bacteria by optimizing the conditions for the fermentation of sugar. More than 150 different monomers can be combined within this family to give materials with extremely different properties. PHA is more ductile and less elastic than other plastics, and it is also biodegradable. These plastics are being widely used in the medical industry.

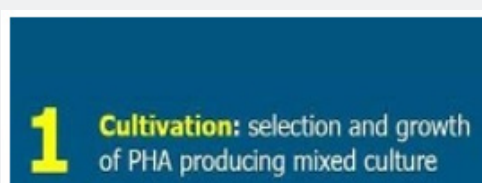

PHA production: maximizing the cellular PHA content

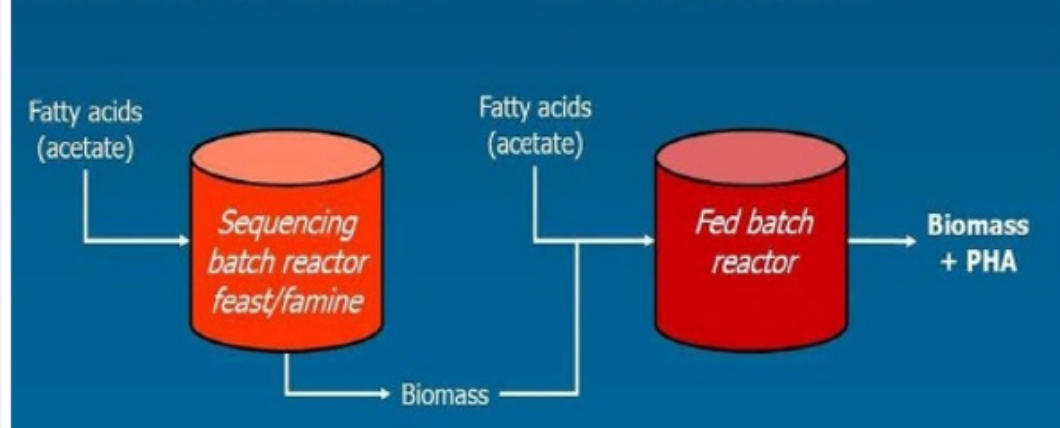

Figure 9: Production of PHA from fatty acids. 


\section{Poly-3-Hydroxybutyrate (PHB)}

Magda etal. [37], defined Biopolymerpoly-3-Hydroxybutyrate (PHB) as polyesters produced by certain bacteria processing glucose, corn starchor waste water. Its characteristics are similar to those of the petroplastic polypropylene. PHB production by bacteria is increasing every year [38]. Chen \& Patel [39], also discovered that South American sugar industry, for example, has decided to expand PHB production to an industrial scale. PHB is distinguished primarily by its physical characteristics. It can be processed into a transparent film with a melting point higher than 130 degrees Celsius and is biodegradable without residue (Figure 10).

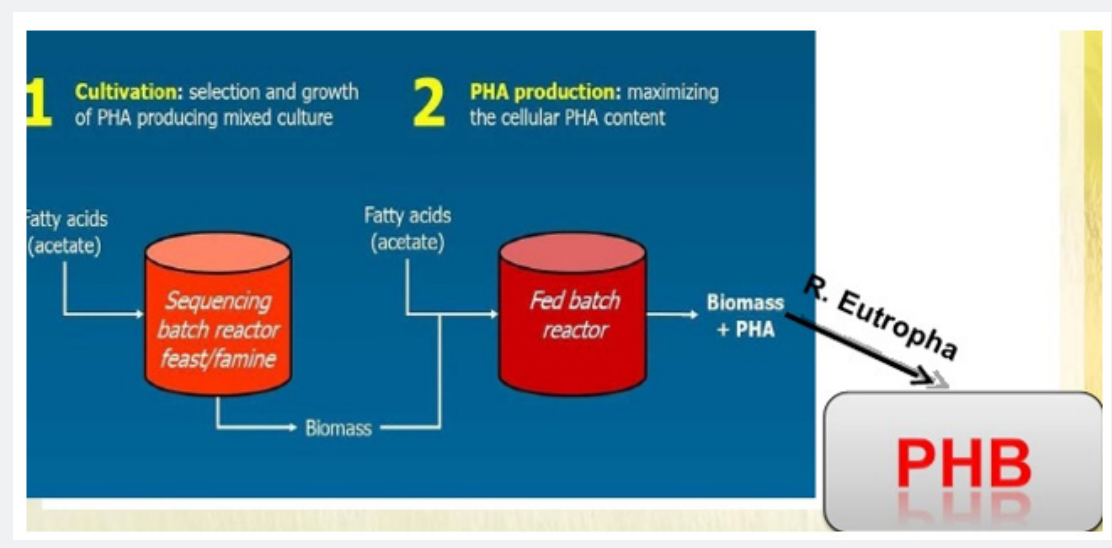

Figure 10: Industrial production of PHB.

\section{Polyamide (PA 11)}

Polyamide 11 is a biopolymer derived from natural oil. It is also known under the tradename Rilsan B, commercialized by Arkema PA 11 belongs to the technical polymers family and is not biodegradable. Its properties are similar to those of PA 12, although emissions of greenhouse gases and consumption of nonrenewable resources are reduced during its production. Its thermal resistance is also superior to that of PA 12. It is used in high-performance applications like automotive fuel lines, pneumatic airbrake tubing, electrical cable anti-termite sheathing, flexible oil and gas pipes, control fluid umbilicals, sports shoes, electronic device components, and catheters. Polyamide 410 (PA 410) is another closely related bioplastic made from castor [40].

\section{Polyethylene Derived from Biomass}

Ethylene is the monomer for the formation of polyethylene. Ethylene may be derived from ethanol and is chemically similar to it. Polyethylene may be synthesized by fermentation of agricultural feedstocks such as sugar cane or corn. Bio-derived polyethylene though non-biodegradable may be recycled and is chemically and physically identical to traditional polyethylene. Bio derivation of polyethylene can also reduce or eliminate greenhouse gas emissions considerably. Thus bio-ethylene is a type of bioplastic.

\section{Polyamide (PA 11)}

Polyamide 11 is a biopolymer derived from natural oil. It is also known under the tradename Rilsan B, commercialized by Arkema [39]PA 11 belongs to the technical polymers family and is not biodegradable. Its properties are similar to those of PA 12 , although emissions of greenhouse gases and consumption of nonrenewable resources are reduced during its production.
Its thermal resistance is also superior to that of PA 12. It is used in high-performance applications like automotive fuel lines, pneumatic airbrake tubing, electrical cable anti-termite sheathing, flexible oil and gas pipes, control fluid umbilicals, sports shoes, electronic device components, and catheters. Polyamide 410 (PA 410) is another closely related bioplastic made from castor.

\section{Polyethylene Derived from Biomass}

Ethylene is the monomer for the formation of polyethylene. Ethylene may be derived from ethanol and is chemically similar to it. Polyethylene may be synthesised by fermentation of agricultural feedstocks such as sugar cane or corn. Bio-derived polyethylene though non-biodegradable may be recycled and is chemically and physically identical to traditional polyethylene. Bio derivation of polyethylene can also reduce or eliminate greenhouse gas emissions considerably.Thus bio-ethylene is a type of bioplastic.

\section{Genetically modified Bioplastics}

Genetically Modification (GM) of any biosource may be a great potential for bioplastic synthesis. For instance, genetically modifying fungi, algae, bacteria and plants by finding a way of increasing the PHAs, PBHs, PHH, PLA and other is a mean of encouraging their harvest for synthesis into bioplastics. Genetic engineering and biotechnological innovations are possibilities of achieving these.

\section{Conclusion}

Commercial production of bioplastic may be costly currently, but in future with more technological advancement, it is a great and viable venture. Efforts are already ongoing in this quest as some research have shown their possibilities. Bio-plastics 
currently in the market are of minimal usage for specialty purposes in medical, food and other consumable packages. It is the way to go in future since it will eliminate all the environmental challenges imposed by the conventional petroleum hydrocarbon derived plastics.

\section{References}

1. Ezeonu CS, Sindama A, Ezeonu NC, Onwurah INE (2016) Effect of Crude Oil and Soluble Metal Salt Contaminated Soil on Zea Mays Plant Growth Indices. FUW Trends in Science and Technology Journal 1(1): 243-247.

2. Ezeonu CS, Ezeonu NC (2016) Alternative Sources of Petrochemicals from Readily Available Biomass and Agro-Products in Africa: A Review. Journal of Petroleum and Environmental Biotechnology 7: 301.

3. Braunegg GJ, Lefebvre G, Genser KF (1998) Polyhydroxyalkanoates, biopolyesters from renewable resources: Physiological and engineering aspects. J Biotechnol 65(2-3): 127-161.

4. Dawes E (1990) Novel Biodegradable Microbial Polymers. Dordrecht, The Netherlands: Kluwer Academic Publishers.

5. Lemoigne M (1926) product de dehydration et de de hydratation et depolymerization de lácide $\beta$ - oxo butyrique. Bulletin de la sociètè de chimie Biologique 8: 770-782.

6. Avella M, Vlieger J, Errico EM, Fischer S, Vacca P, et al. (2005) Biodegradable starch/clay nanocomposite films for food packaging applications. Food Chemistry. 93 (3): 467-474.

7. Averous L, Pollet E (2012) Biodegradable Polymer Environmental silicate nano-bio composites. Green Energy Technology, Springer Verlag, London.

8. Agnieszka G, Natalia G, Helena J (2011) Biodegradable polymer for food packaging- factors influencing their degradation and certification typesa comprehensive review. Chemistry and Chemical Technology 5(1): 115122

9. Heap B (2009) Philosophical Transactions of the Royal Society. Biological Sciences 364: 1971-1971.

10. Asta E (2007) WPCS- an European Market overview, wood fibre polymer composites international Symposium 2007, Bordeaux.

11. Frost, Sullivian (2007) European Markets for bioplastics, Mi 36-39.

12. Hong C, Peter HFY, Chee KM (1999)"Accumulation of biopolymers in activated sludge biomass". Appl Biochem and Biotechnol 78: 389-399.

13. Jajani GS, Rajarajan R (2012) Presentation on bioplastics, CEG Anna University, compostable plastic. Slide $6-7$, Accessed ( $5^{\text {th }}$ ed).

14. Reddy CSK, Ghai R, Rashimi, Kalia VC (2003) Polyhydroxyalkanoates, an overview. Bioresour Technol 87(2): 137-146.

15. www.treehugger.com/algae_plastics

16. Verlinden RAJ, Hill DJ, Kenward MA, Williams CD, Radecka I (2007) Bacterial synthesis of biodegradable Polyhydroxyalkanoates. J Appl Microbiology 102(6): 1437-1449.

17. Dawes E (1990) Novel Biodegradable Microbial Polymers. Dordrecht, The Netherlands: Kluwer Academic Publishers.

18. Priyanka S, Rajam R (2011) Bioplastics: current trend and future prospects. School of Bio Sciences and Technology VIT University, Vellore - 632 014, India.

19. De Graff RA, Jassen L (2004) The production of a new partially biodegradable starch plastic by relative extrusion. Polymer Engineering Science 40: 2086-2094.

20. Ken TY, Sun XZ (2000) Physical Properties of Poly (lactic acid) Starch Composite with various blending ratios. Cereal Chemistry 77(6): 761768
21. Ramesh M, Mitchell JR, Handung SE (1999) Amylase content of rice starch. Starch 51: 311-363.

22. Thomasik P, Schulling CH (2004) Chemically Modification of Starch. Adv Carbohydr Chem Biochem 59: 175-403.

23. Liu L (2006) Bioplastics in Food Packaging; Innovative Technologies for Biodegradable Packaging.

24. Flieger M, Kantorova M, Prell A, Rezanka T, Votruba J (2003) Biodegradable Plastics from Renewable Sources. Folia Microbiology 48(1): 27-44.

25. Cyras VP, Commisso MS, Vazquez A (2009) Biocomposites based on renewable resources: acetylated and non-acetylated cellulose cardboard coated with polyhydroxy butyrate. Polymer 50(26): 6274-6280.

26. Peterson K, Nielsen PV, Bertelsen G, Lawther M, Olsen MB, et al. (1999) Potential of Biobased Materials for Food Packaging. Trends in Food Science and Technology 10(2): 52-68.

27. Weber CJ (2000) Biobased packaging material for the food industry, status and perspective.

28. Zepnik S, Kesselring A, Kopitzky R, Michels C (2010) Basic Cellulosic. Bioplastics Magazine. 1: 44-47.

29. Thakur BR, Singh RK, Handa AV (1997) Chemistry and uses of pectin -A Review. Critical Reviews in Food Science and Nutrition. 37(1): 47-73.

30. May CD (1990) Industrial Pectins: Sources, Production and Applications. Carbohydrate Polymer 12(1): 79-99.

31. Malathi AN, Santhosh KS, Udaykumar N (2014) Recent trends of Biodegradable polymer: Biodegradable films for Food Packaging and application of Nanotechnology in Biodegradable Food Packaging. Current Trends in Technology and Science. 3(2): 73-79.

32. Rinaudo M (2006) Chitin and Chitosan Properties and Application. Polymer Science 31(7): 603-632.

33. Itoh Y, Kawase T, Nikaidou N, Fukada H, Mitsutonii M, et al. (2002) Functional Analysis of Chitin Blending domain of a family 19 Chinitase from Streptomyces griseus HUT6031; substrate blending affinity and Cisdominate increase of antifungal function. Bioscience Biotechnology, Biochemistry 66: 1084-1092.

34. Sorrentino A, Gorrasi G, Vittoria V (2007) Potential Perspective of Bionanocomposites of Food Packaging Applications. Trends in Food Science and Technology 18(2): 84-95.

35. Royte E (2006) Corn plastic to the Rescue. Smithsonian Magazine.

36. Suszkiw J (2005) “Electroactive Bioplastics Flex Their Industrial Muscle”. News and Events. USDA Agricultural Research Service. Retrieved 11-28.

37. Magda MA, Ghofran NR, Lubna N (2017) Factors Affection Degradation of Poly-3-Hydroxybutyrate (Bioplastic) By A Filamentous Bacterium of the Genus Streptomyces. IOSR Journal of Pharmacy and Biological Sciences, 12(6): 65-70.

38. Gouda MK., Swellam AE, Omar SH (2001) Production of PHB by a Bacillus megateriumstrain using sugarcane molasses and corn steep liquor as sole carbon and nitrogen sources. Microbiology Resources156(3): 201-207.

39. Chen G, Patel M (2012) Plastics derived from biological sources: Present and future: P Technical and Environmental Review. Chem Rev 112(4): 2082-2099.

40. https://www.lookchem.com/Chempedia/Basic-Chemical/ChemicalNoun-Definition/15227.html 
This work is licensed under Creative Commons Attribution 4.0 Licens DOI: 10.19080/AIBM 2018.10.555797
Your next submission with Juniper Publishers will reach you the below assets

- Quality Editorial service

- Swift Peer Review

- Reprints availability

- E-prints Service

- Manuscript Podcast for convenient understanding

- Global attainment for your research

- Manuscript accessibility in different formats ( Pdf, E-pub, Full Text, Audio)

- Unceasing customer service

Track the below URL for one-step submission https://juniperpublishers.com/online-submission.php 